\title{
Phytochemical screening antioxidant and antimicrobial activity of aeschynomene aspera linn root extract
}

\author{
K.Iswaryalakshmi ${ }^{1}$, M.Akilabalamurugan ${ }^{2 *}$ \\ ${ }^{1}$ Scholar, ${ }^{2}$ Assistant Professor, ${ }^{1}$ Dept. of Biochemistry, Rabiammal Ahamed Maideen College for Women, Tiruvarur, Tamil Nadu, India \\ *Corresponding Author: M.Akilabalamurugan \\ Email:makila2705@gmail.com
}

\begin{abstract}
Medicinal plant are the nature's of gift to human being to make disease free healthy life.It play a vital role to preserve our health. In india different part have been used for curing various diseases from ancient life. In this present study focus on the analysis of priliminary phytochemical in ethanol extract of Asechynomene Aspera Linn root. Among this extract presence of therapeutically important and valuable secondary metabolites flavonoids, alkaloids, trephenoids, steriods and phenol. The antioxidant activity of root sample was evaluvated by using DPPH, ABTS and Nitric oxide reducing activity. The present study showed that good free radical scavenging properties and a clear correlation exist between the antioxidant activity. The ethanolic extract of AsechynomeneAspera Linn root sample was tested for its antibacterial activity against two human bacterial pathogens (E.coli and S.pneumoniae) and using three different concentration by disc diffusion method.The maximum inhibition of antibactrial activity was observed in E.coli. The study concluded that the ethanolic extract of Asechynomene Aspera Linn root has potential antioxidant and antimicrobial action which is responsible for the biological activities that is used for natural health.
\end{abstract}

Keywords: Asechynomene aspera Linn, DPPH, ABTS, Nitric Oxide,

\section{Introduction}

Free radicals are naturally produced in the body through normal metabolism of biomolecules like carbohydrates, amino acids and fats. Over production of free radicals cause oxidation of these biomolecules which can lead to a variety of diseases such as cancer, cardiovascular diseases, cataracts, diabetes, and inflammatory diseases along with induces deterioration of food, resulting in rancidity, changes in color, and declines in nutritional quality, flavor, texture and safety. Antioxidants are chemical compounds that can bind to free oxygen radicals and preventing these radicals from damaging healthy cells and it can be added to food products especially lipid containing food to increase the shelf life of foods. Commonly used synthetic antioxidants like butylated hydroxyanisole (BHA) and butylated hydroxytolune (BHT) are suspected to cause some safety concerns because theirconsumption may cause cancer and liver damage. Therefore, the search for alternative sources of natural antioxidant is becoming increasingly important (Mohammad Mohiseni et al.,2017).

Phytochemicals are non- nutritive plant chemicals that have protective or disease preventive properties. They are non-essential nutrients, meaning that they are not required by the human body for sustaining life. It is well-known that plants produce these chemicals to protect themselves but recent research demonstrates that they can also protect against diseases. There are more than thousand known phytochemicals. Some of the well-known phytochemicals arelycopene in tomatoes, Isoflavones in soy and flavonoids in fruits. Phytochemicals are naturally present in many foods but it is expected that through bioengineering new plants will bedeveloped, which will contain higher levels of phytochemicals. This would make it easier to incorporate enough phytochemicals with our food (Mercy Gospel Ajuru et al.,2017)
Microorganism are evolved with numerous defences against commercially available powered the anitimicrobial research toward sthe screening of natural products to fight against the dreadful microorganism (Silver L and Bostian $\mathrm{K})$.In recent years, secondary metabolites (phtochemicals), previously with unkonown pharmacological activities, have beeen extensively. Investigated as asourse of medicinal agents (Krishnaraju et al., 2005) thus,it is anticipatd that phytochemicals with adequate antibacterial efficay will be used for te treatment o antibacterial infection(Balandrin et $a l ., 1985)$. Antibacterial activity is method to destroying or suppressing the growth or reproduction of bacteria. The term antibacterial terms derives from Greek word -antill that means against. The compound which destroys or suppresses the growth or reproduction of bacteria, and that type of compound or agent having such properties is called antibacterial agent or antibacterial compounds. These are the either drugs or any plants material that destroy or inhibit the growth of bacteria, chemotherapeutic agents also having ability to prevent or treat bacterial infections. Hence the present study was designed to analyze the Anti microbial \& antioxidant capacity of Asechynomene Aspera Linn with different invitro models

\section{Materials and Methods Collection of Plant}

The fresh root samples of Asechynomene Aspera Linn was collected from Thiruvarur district, Tamil Nadu, India. The root first washed well and dust removed from the plant and were dried at room temperature. The dried material were to powder from with a mixer grinder and stored in air tight container for further use.

\section{Preparation of Ethanolic Extracts}


The powdered root samples Asechynomene Aspera Linn $(50 \%)$ were weighed and mixed with $(50 \%)$ of methanol. Then it is kept in an orbital shaker at 190-220 rpm for 48 hours. The supernatant was collected, filtered through Whatman No.1 filter paper and then concentrated by evaporating to dryness which gave a solid amorphous residue and it was dried thoroughly to remove the solvent used. The obtained dried extract was then accurately weighed, stored in a small vials and used for the subsequent expeiments.

\section{Qualitative Analysis of Phytochemicals}

Phytochemical analysis of Asechynomene Aspera Linn was done the ethanolic extract was analysed alkaloids, flavonoids, saponin, protein coumarn, phenols, triterepene, steroids, tannins. According to standard methods of harborns (1973)

\section{In Vitro Antioxidant Assay DPPH radical scavenging activity}

Free radical scavenging activity of extracts of Asechynomene Aspera Linn were tested by its ability to bleach the stable 1,1-diphenyl 2-picryl-hydrazyl (DPPH) radical. A stock solution of DPPH $0.3 \mathrm{mM}$ in methanol) was prepared such that $1 \mathrm{ml}$ of it in $3 \mathrm{ml}$ methanol gave an initial absorbance of 0.9.Decrease in absorbance in the presence of Ethanolic extract at different concentration $(50-500 \mathrm{mg} / \mathrm{ml}$ ) were noted after $15 \mathrm{~min}$. scavenging activity was expressed as the\%inhibition (Ionita,2005; Ji-Kai Liu et al.,2004).

Radical scavenging activity $(\%)=\frac{\text { OD Control-OD sample }}{\text { OD control }} \times 100$

\section{ABTS radical cation decolourisation assay}

ABTS (54.8 mg) was dissolved in $50 \mathrm{ml}$ of distilled water to $2 \mathrm{mM}$ concentration and potassium persulphate $(17 \mathrm{mM}, 0.3$ $\mathrm{ml})$ was added. The reaction mixture was left to stand at room temperature overnight in dark before use. To $0.2 \mathrm{ml}$ of various concentrations of the extracts or standards, $1.0 \mathrm{ml}$ of distilled DMSO and $0.16 \mathrm{ml}$ of ABTS solution was added to make a final volume of $1.36 \mathrm{ml}$. Absorbance was measured spectrophotometrically, after $20 \mathrm{~min}$ at $734 \mathrm{~nm}$. The assay was performed in triplicate (Jayaprakasha et al., 2004).

\section{Nitric Oxide Scavenging Assay}

The method of DC Garrat, 1964 was followed. To $0.5 \mathrm{ml}$ of varying concentration of extract, $2 \mathrm{ml}$ of $(10 \mathrm{mM})$ sodium nitropruside, $0.5 \mathrm{ml}$ of phosphate buffer saline (pH-7.4)was added and incubated at $250 \mathrm{C}$ for $21 / 2$ hours. To $0.5 \mathrm{ml}$ of this reaction mixture $1 \mathrm{ml}$ of $(0.33 \%)$ sulfannilic acid was added and allowed to stand at room temperature for 5minutes. Then $1 \mathrm{ml}$ of $(0.1 \%)$ naphthylene diamine chloride was added and incubated at room temperature for 30 minutes. Absorbance was read at $540 \mathrm{~nm}$.\% inhibition was calculated as above.

\section{Antibacterial Activity}

The antibacterial activity of various solvent extracts like aqueous and ethanol solution were studied systematically against two different strains of bacteria (Escherichia coli and streptococcus pneumoniae) by cup diffusion method.

\section{Results and Discussion}

Plant have provided a sources of inspiration for novel drug compounds as plant derived medicines have made significant contribution towards human health, phytomedicines can be used for the treatment of disease as done in case of Unani and Ayurvedic system of medicines or it can be the base for the development of a medicine, a natural blue print for the development of a drug (Didry et al., 1998). For over thousands of years, natural plants have been used as a valuable source of medicinal agents with proven potential of treating infectious disease and with lesser side effects compared to synthetic drug agents (Iwu et al., 1999).

The freshly prepared extract Aeschynomene aspaera linn $\mathrm{w}$ as subjected to preliminary phytochemical screening test for various constituents. This revealed the presence of phenol, sterol, alkaloids, flavonoids and Terpenoids (Table 2 ). The results of phytochemical analysis comprehensively validate the presence of therapeutically important and valuable secondary metabolites (alkaloids, flavonoids, phenol and steroids) in the root of plant. They also provide a source of medicine since the earliest time.

Phytochemicals are referred to as phytonutrients. These are compounds present in plant derived-foods that induce biological activities in the body. Balandrin et al., 1985 reported that the phytonutrients promote the function of the immune system, act directly against bacteria and viruses, reduces inflammation and are also associated with the treatment and prevention of cancer, cardiovascular disease.

Table 1: Phytochemical analysis of Ethanolic extracts of Asechynomene Aspera Linn Root

\begin{tabular}{|c|c|c|}
\hline Phytochemicals & Observation & $\begin{array}{c}\text { Ethanolic Asechynomene Aspera } \\
\text { Linn Root extracts }\end{array}$ \\
\hline Carbohydrate & Red colour & - \\
\hline Tannins & Greenish black colour & - \\
\hline Saponin & Presence of foam & - \\
\hline Flavonoid & Yellow colour & + \\
\hline Glycosides & Yellow colour & + \\
\hline Terpenoids & Red brown colour & + \\
\hline Phenols & Green Colour & - \\
\hline
\end{tabular}




\begin{tabular}{|c|c|c|}
\hline Alkaloids & White turbidity & + \\
\hline Resins & Orange to yellow colour & - \\
\hline Steroids & violet to blue colour formed & + \\
\hline
\end{tabular}

+: Present, -: Absent,

\section{DPPH free Radical Scavenging}

To determine the efficacy of natural antioxidants either as pure compounds or as plant extract, a great number of in vitro methods have been developed in which antioxidant compounds act by several mechanisms. DPPH scavenging activity was shown in Table 2; Figure 1 . In the present study, the percentage of scavenging effect on the DPPH radical was concomitantly increased with the increased concentration of ethanolic extract from 50 to $250 \mu \mathrm{g} / \mathrm{ml}$. The percentage of inhibition exists from 12 at $50 \mu \mathrm{g} / \mathrm{ml}$ to 60 at $250 \mu \mathrm{g} / \mathrm{ml}$ and values were compared ascorbic acid standard. IC50 values of Aeschynomene aspaera linn was compared with ascorbic acid. IC50 value of standard was $250 \mu \mathrm{g} / \mathrm{ml}$ and plant extract was $208 \mu \mathrm{g} / \mathrm{ml}$.

\section{ABTS Radical Scavenging Activity}

This study reports that whole plant have radical scavenging activity. The percentage of inhibition was existing from 18 to 72 at the concentration of $50 \mu \mathrm{g} / \mathrm{ml}$ to $250 \mu \mathrm{g} / \mathrm{ml}$ for whole plant extract. From the result showed ABTS radical scavenging activity and compared with ascorbic acid as standard. IC50 values plant extract and ascorbic acid were $150 \mu \mathrm{g} / \mathrm{ml}$ and $141 \mu \mathrm{g} / \mathrm{ml}$ respectively Table 3;Fig 2). Based on the above results indicated, the whole plant was found to most effective in exhibiting in vitro antioxidant activity in this method. ABTS was generated by incubating ABTS chromophore through the reaction (Wolfenden et al., 1981). The presence of specific chemical compound in the extract may inhibit the potassium persulfate activity and hence reduced the production of ABTS.

\section{Nitric Oxide Scavenging Activity}

Nitric oxide is a very unstable species and reacting with oxygen molecule produce stable nitrate and nitrite which can be estimated by using Griess reagent. In the presence of a scavenging test compound, the amount of nitrous acid will decrease which can be measured at $546 \mathrm{~nm}$. Extract of Aeschynomene aspaera linn has potent nitric oxide scavenging activity (IC50 value $200 \mu \mathrm{g} / \mathrm{ml}$ ). The scavenging of NO by the extracts was increased in dose dependent manner. Table 4;Fig. 3 illustrates a significant decrease in the NO radical due to the scavenging ability of extracts and ascorbic acid. The ethanolic extract showed maximum activity of $65 \%$ at $250 \mu \mathrm{g} / \mathrm{ml}$, where as ascorbic acid at the same concentration exhibited 55\% inhibition.

\section{Antimicrobial Activity}

Medicinal plant could be that alternative because most of them are safe with little side effects if any,cost less and affect a wide range of antibiotic resistance microorganism. The result of this study showed that two plant extracts tested inhibit the growth of various species of gram positve and gram negative bacteria (Al-Habib et al., 2010). The present study Asechynomene Aspera Linn activity were analyzed against E.Coli and Streptococcus Pneuoniae. the highest antibacterial activities were observed in ethanol extract compared with aquesous extract.The result of the this study, we will further investigate the plant that showed antioxidant and anitibacterial activities in vivo studies (Table 5)

Table 2: DPPH radical scavenging activity of Asechnomene Aspera Linn

\begin{tabular}{|c|c|l|}
\hline S. No & Concentration $(\mathbf{m g} / \mathbf{m l})$ & \multicolumn{1}{c|}{ \% of Scavenging activity } \\
\hline 1 & 50 & 5 \\
\hline 2 & 100 & 20 \\
\hline 3 & 150 & 35 \\
\hline 4 & 200 & 40 \\
\hline 5 & 250 & 55 \\
\hline
\end{tabular}

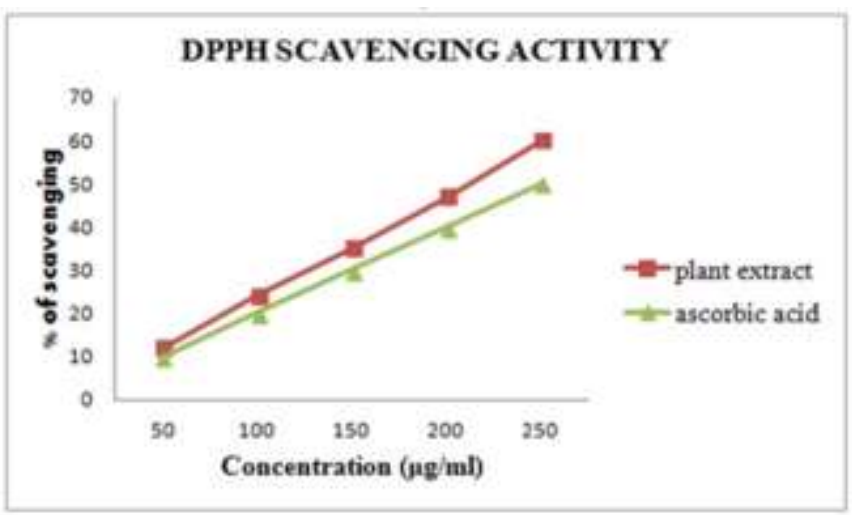

Fig 1: DPPH radical scavenging activity of Asechnomene Aspera Linn 
Table3: ABTS radical scavenging activity of Asechnomene Aspera Linn

\begin{tabular}{|c|c|c|}
\hline S. No & Concentration $(\mathbf{m g} / \mathbf{m l})$ & \% of scavenging activity \\
\hline 1 & 50 & 15 \\
\hline 2 & 100 & 35 \\
\hline 3 & 150 & 50 \\
\hline 4 & 200 & 60 \\
\hline 5 & 250 & 75 \\
\hline
\end{tabular}

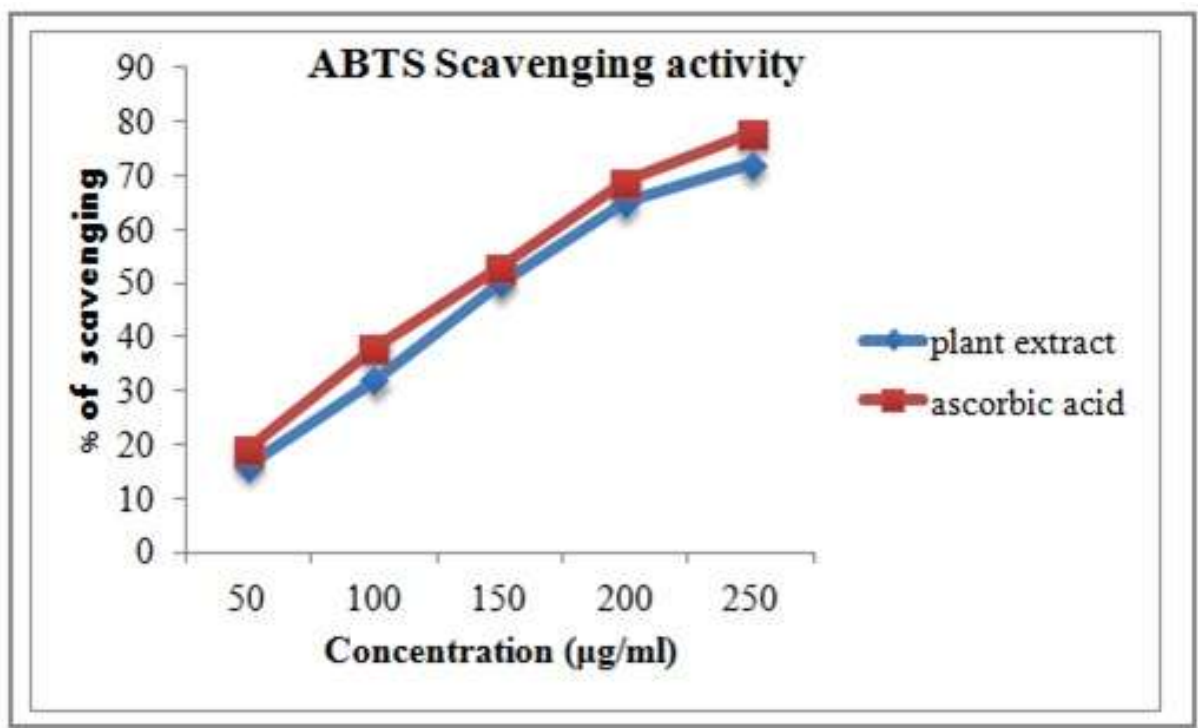

Fig 2: ABTS radical scavenging activity of Asechnomene Aspera Linn

Table 4: Nitric oxide scavenging activity of Asechnomene Aspera Linn

\begin{tabular}{|c|c|c|}
\hline S. No & Concentration $(\mathbf{m g} / \mathbf{m l})$ & \multicolumn{1}{c|}{$\%$ of scavenging activity } \\
\hline 1 & 50 & 10 \\
\hline 2 & 100 & 25 \\
\hline 3 & 150 & 35 \\
\hline 4 & 200 & 40 \\
\hline 5 & 250 & 55 \\
\hline
\end{tabular}

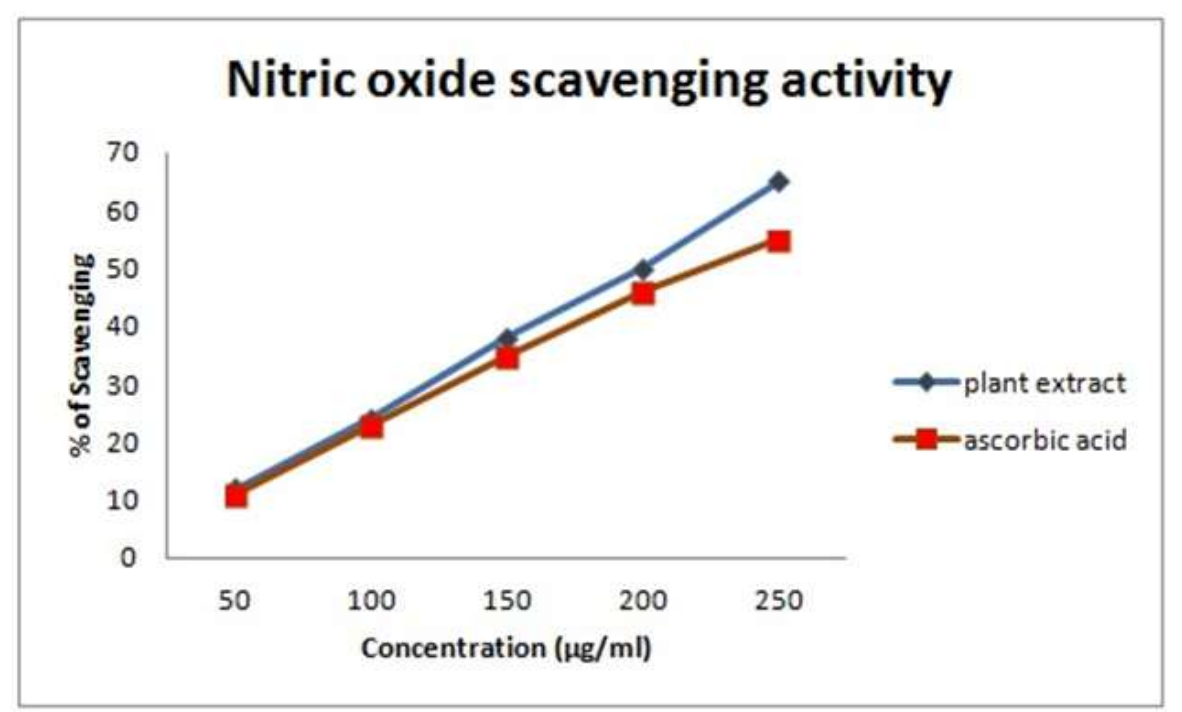

Fig. 3: Nitric oxide scavenging activity of Asechnomene Aspera Linn 
Table 5: Antibacterial activities exhibited by different solvent extracts of Asechynomene Aspera Linn

\begin{tabular}{|l|c|c|c|c|c|c|}
\hline \multicolumn{1}{|c|}{ Bacterial pathogens } & \multicolumn{3}{|c|}{ Asechynomene Aspera Linn Zone of Inhibition(mm) } \\
\hline Concentration (ug/ml) & \multicolumn{3}{|c|}{ Aqueous } & \multicolumn{3}{c|}{ Ethanol } \\
\cline { 2 - 7 } & 50 & 100 & 150 & 50 & 100 & 150 \\
\hline E. coli & 2 & 5 & 7 & 5 & 8 & 1 \\
\hline Streptococcus pneumonia & 3 & 5 & 8 & 7 & 9 & 13 \\
\hline
\end{tabular}

\section{Conclusion}

From the above study, is conclude that the Aeschynomene aspaera linn root was rich in phytoconstituents like flavonoids, alkaloids, steroids, teriphenoids and phenols. In conclusion, the observed different scavenging activities of Aeschynomene aspaera linn root extract against various systems may be referred to the different mechanism of the radical antioxidant reactions in the different assays. Phenolic compounds present in the plant kingdom are mainly responsible for the antioxidant potential of plants. Free radical scavenging activity of Aeschynomene aspaera linn root might be due to the presence of high molecular weight phenolics. The extracts exhibited remarkable radical scavenging capacity rendering their utilization in different ailments associated with oxidative stress. Thus it can be concluded that the whole plant of Aeschynomene aspaera linn root can be used as an accessible source of natural antioxidants with consequent health benefits. However, the components responsible for the antioxidative activity are currently unclear. Antibacterial activity of different concentration $(50,100,150 \mathrm{ug} / \mathrm{ml})$ of ethanol and aqueous extract of Asechynomene Aspera Linn was screened against the pathogenic microorganism by disc diffusion method the extend of antimicrobial activity is varied depending upon the solvent that has been used the ethanolic extract of plant showed higher activity against and Streptococcus Pneuoniae when compared with aqueous extracts.From the present studies a conclusion can be drawn that consumption of Asechynomene Aspera Linn have good beneficial effect.

\section{Conflict of Interest: None.}

\section{Reference}

1. Al-Habib A, Al-Saleh E, Safer A-M, Afzal M(2010)

Bactericidal effect of grape seed extract on methicillin-resistant Staphylococcus aureus (MRSA) Japanese Soc Toxicol 35:35764.

2. Alluri V. Krishnarajua, Tayi V. N. Raoa, Dodda Sundararajua, Mulabagal Vanisreeb, Hsin-Sheng Tsayb, and Gottumukkala
V. Subbaraju. Assessment of Bioactivity of Indian Medicinal Plants Using Brine Shrimp (Artemia salina) Lethality Assay. Int J Appl Sci Eng 2005;3;2:125-134.

3. Balandrin M.F., Klocke J.A., Wartele E.S. and Bollingen W.H. Natural plant chemicals: sources of Industrial Medicinal materials. Sci 1985;228:1154-60.

4. Garrat DC. The quantitative analysis of drugs. Japan Chapman \& Hall 2nd edition, 1964;(3): 342.

5. Didry N, Dubreul L, Trotin F, Pinkas M. Antimicrobial activity of the aerial parts of the drosera pellagra smith on oral bacteria. J Ethnopharmacol 1998;60:91-6.

6. Harborne J, (1973).Phytochemical methods. Chapman and Hall, Ltd London; p.49-88.

7. Ionita P. Is DPPH Stable free radical a good scavenger for oxygen active species? Chem 2005;59,11-6.

8. Iwu MM, Duncan AR, okunji CO. New antimicrobials of plant origin. In: prospective on New Crops and New Uses, Janick J. Ed. ASHS press; 457-62. 1999.

9. Jayaprakasha G.K., Lingamallu J R., Kunnumpurath K S. Antioxidant activities of Flavidin in Different In vitro Model Systems. Bioorganic Med Chem 2004;12:5141-6.

10. Ji-Kai Liu, Lin Hu, Ze-Jun Dong, and Qun Hu. DPPH Radical Scavenging Activity of Ten Natural p-Terphenyl Derivatives Obtained from Three Edible Mushrooms Indigenous to China, Chem Biodiver 2004;1:601-5.

11. Mercy Gospel Ajuru, Light Femi Williams, Gospel Ajuru. Qualitative and Quantitative Phytochemical Screening of Some Plants Used in Ethnomedicine in the Niger Delta Region of Nigeria. J Food Nutr Sci 2017;5(5):198-205.

12. Mohammad Mohiseni, Mehrdad Farhangi, Naser Agh, Alireza Mirvaghefi, Khalil Talebi, Toxicity and Bioconcentration of Cadmium and Copper in Artemia Urmiana Nauplii Iranian. $J$ Toxicol 2017;11(1);33-41.

13. Silver L and Bostian K. Screening of natural products for antimicrobial agents. Eur J Clin Microbiol Infect Dis 1990;9(7):455-61.

14. Wolfenden, R., Andersson, L., Cullis, P. M. \& Southgate, C. C. B. Biockmicstry 1981;20;849-55.

How to cite this article: Iswaryalakshmi $\mathrm{K}$, Akilabalamurugan M. Phytochemical screening antioxidant and antimicrobial activity of aeschynomene aspera linn root extract. J Pharm Biolog Sci 2019;7(1):29-33. 